\title{
Eesti keele käekäik 21. saj alguses
}

\section{Birute Klaas-Lang}

\section{OpenEdition}

Journals

Édition électronique

URL : https://journals.openedition.org/efo/882

DOI : $10.4000 /$ efo 882

ISSN : 2275-1947

Éditeur

INALCO

\section{Édition imprimée}

Date de publication : 1 décembre 2012

ISBN : 978-2-343-02592-6

ISSN : 0071-2051

\section{Référence électronique}

Birute Klaas-Lang, «Eesti keele käekäik 21. saj alguses », Études finno-ougriennes [En ligne], 44 | 2012,

mis en ligne le 20 mars 2014, consulté le 11 juillet 2021. URL : http://journals.openedition.org/efo/882 ; DOI : https://doi.org/10.4000/efo.882

Ce document a été généré automatiquement le 11 juillet 2021.

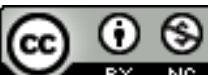

Études finno-ougriennes est mis à disposition selon les termes de la Licence Creative Commons Attribution - Pas d'Utilisation Commerciale 4.0 International. 


\title{
Eesti keele käekäik 21. saj alguses
}

\author{
Birute Klaas-Lang
}

\section{Sissejuhatus}

1 Kuigi keelel on kanda erinevaid ülesandeid, võime riigikeele puhul prioriteetseimaks seada funktsiooni olla riikliku, vaimse ja kultuurilise terviklikkuse määraja. Mahuvad ju keele muud funktsioonid (suhtlemisvahend, rahvusliku identiteedi alus, kultuurimälu kandja jne) selle üldise, terviklikkust rõhutava diskursuse sisse.

2 Artiklis leiab käsitlust eesti keele seisund Eesti riigikeelena väga erinevatest aspektidest. Autor annab oma artiklis ülevaate Eesti keelevaldkonna õiguslikust regulatsioonist ja strateegilisest planeerimisest, eelkõige viimase kümnendi tegevustest eesti keele positsioonide kindlustamisel erinevates kasutusvaldkondades.

3 Eesti keel oma miljoni emakeelse kasutajaga ei kuulu sotsiolingvistiliste määratluste järgi ohustatud keelte hulka, sest eesti keelel on

- riigikeele staatus;

- keelt kasutatakse kõikides kasutussfäärides argikeelest ettevõtluse ja teaduseni;

- keel on õppekeeleks kõigis haridusastmetes, põhikoolist doktoriõppeni;

- keelt räägitakse kodudes ja keelel on järelkasv;

- eesti keelel on arvutitugi.

4 Siiski nõuab kaasaegne globaliseeruv maailm erilist tähelepane keele vitaalsuse säilitamisele ka sel juhul, kui seda keelt kasutab üle miljoni emakeelse kõneleja. Kindlasti on üks võtmepositsioonil kasutusvaldkondadest kõrgharidus ja teadus. Artiklis pöörataksegi erilist tähelepanu eesti keelele kõrghariduse ja teaduse keelena.

\section{Statistilised andmed Eesti elanikkonna rahvuslikust ja emakeele alasest jaotusest}

5 Eesti Statistikaameti andmetel oli Eesti rahvaarv 2010. aastal 1, 32 milj elanikku. Eesti on oma elanike arvu poolest üks väiksemaid Euroopas, jäädes nö keskmisele Euroopa 
Liidu liikmesriigi näitajale elanike arvu poolest alla koguni 14 korda. Rahvustest on esindatud eestlased $(68,8 \%)$, venelased $(25,5 \%)$, ukrainlased ja teised rahvad $(5,6 \%)$ (Eesti 2011: 6 - 8). Rahvaarv on väljarände ja madala sündimuse tõttu vähenenud alates 1989. aastast, seejuures mitte-eestlaste seas enam kui eestlaste seas (Eesti inimarengu aruanne 2007: 48). Ka viimased aastad ei ole väljarändu pidurdanud.

6 2000. aasta rahvaloendusel ütles 67,3\% elanikest, et nende emakeel on eesti keel, 29,7\% nimetas emakeelena vene keelt ning ühtki teist keelt ei nimetanud emakeelena üle $1 \%$ inimestest, ehkki erinevate emakeelte arv oli suur (Eesti statistikaamet 2001: 15). Mitteeestlaste eesti keele oskus on hakanud viimastel aastatel järjekindlalt tõusma. Seni läbi viidud uuringute tulemused näitavad, et nende 15-74aastaste mitte-eestlaste osakaal, kes väidavad end eesti keelt oskavat, on kasvanud 34\%lt (1997) 40\%le (2007) (Eesti Statistikaamet)). Ka Eesti lõimumiskava monitooring „Eesti lõimumiskava 2008-2013 visioonieesmärkide saavutamisest aastatel 2008-2009“, mille viis 2010. a läbi Tallinna Ülikooli prof Raivo Vettiku uurimisgrupp, näitab, et venekeelsete inimeste enesehinnangute tulemuste põhjal on nende eesti keele oskus viimastel aastatel paranenud (LK monitooring 2010). Statistiliste andmete analüüs näitab aga siiski seda, et Eestis on veel suur hulk inimesi, kes ei valda ühiskonna- ja tööeluks vajalikul määral riigikeelt.

\section{Keelevaldkonna strateegiline planeerimine Eestis}

7 Keele arengu strateegilisel planeerimisel tuleb tegelda kolme olulise aspektiga: staatuse, korpuse ja haridusega (vt ka Stewart 1968, Ferguson 2006, Wiley 2003, Mansoor $2005 \mathrm{jt})$.

Riiklikud õiguslikud regulatsioonid ja teadlik mainekujundus aitavad tagada keelele vajaliku staatuse, keele kui korpuse teadlik ja teaduslik arendamine kindlustab võimaluse keelt kui paindlikku ja kaasaegset instrumenti kasutada kõigis vajalikes valdkondades, kindlustab kirjakeele ühtse normi ja keeletehnoloogilise toe elektroonilises keskkonnas, haridusega tagame keele (ja just kirjakeele ehk siis ühtse ja normeeritud keelekuju) pärandamise põlvest põlve.

9 Eesti riik on panustanud nüüd juba üle 10 aasta keelevaldkonna strateegilisse planeerimisse. 1998. aastal tegi Vabariigi Valitsus oma 21. aprilli protokollilise otsusega Haridusministeeriumile (praegune Haridus- ja Teadusministeerium) ülesandeks koostada eesti keele arendamise strateegia. 2000. aasta 6. aprillil asutati haridusministri käskkirjaga Euroopa keelteaasta korraldamise Eesti komitee (hilisem Eesti keelenõukogu), mille üheks ülesandeks sai kõnealuse strateegia koostamine. Keelenõukogu on olnud haridus- ja teadusministrit keelepoliitilistes küsimustes nõustav ekspertkogu, kuhu kuuluvad Tartu Ülikooli ja Tallinna Ülikooli professorid, Eesti Keele Instituudi teadlased, Haridus- ja Teadusministeeriumi ja tema allasutuste ametnikud jt keelevaldkonna spetsialistid. Siinkirjutaja on juhtinud keelenõukogu tööd viimased 5 aastat. Uue keeleseaduse järgi on keelenõukogu staatus veelgi tõusmas. Nimelt määratleb Eesti Vabariigi keeleseadus (Keeleseadus 2011: 2.pt, § 7), et „Eesti keelenõukogu nõustab Vabariigi Valitsust keelepoliitika arendamisel ja elluviimisel“. Ühtlasi on nüüd ka seadustatud, et „Riigikogu arutab keelepoliitikat ning eesti keele arengut olulise tähtsusega riikliku küsimusena vähemalt kord kahe aasta jooksul“ (Keeleseadus 2011: 2.pt, §6, lõige (1)). 
10 5. augustil 2004 kiitis Vabariigi Valitsus heaks „Eesti keele arendamise strateegia 2004-2010” (EKAS) ja 25. nov 2010 eelmise strateegilise plaani jätku - „Eesti keele arengukava 2011-2017“ (EKA) ja selle rakendusplaani, mille koostas Haridus- ja Teadusministeerium koostöös Eesti keelenõukoguga. Uus arengukava esitab 13 eesti keele arendamise meedet, mis peavad aitama tagada eesti keele kui riigikeele toimimise kõikides eluvaldkondades, selle arenguvõime ning Eesti elanike ühise suhtluskeele staatuse. Arengukava käsitleb eesti keelekorraldust (üld-, oskus- ja nimekorraldus), eesti keele uurimist ja keelekogusid, eesti keele keeletehnoloogilist tuge, haridust ja eesti keele õpet (eestikeelset üldharidust, eesti keelt muukeelses üldhariduses, kutseharidust, kõrgharidust), eesti keele erikujusid (piirkondlikud erikujud, väliseestlaste eesti keel, viipekeel ja keeleliste erivajadustega inimeste keelekasutus), eesti keelt mitmekeelses maailmas, keeleseaduse täitmise järelevalvet ja keeleteavitust.

11 Strateegilistes arengukavades ette nähtud ja kokku lepitud tegevuste elluviimiseks on loomulikult vaja ressursse. Seetõttu on äärmiselt oluline, et arengukavad ja riigi eelarve kujundamine oleksid omavahel kooskõlas. Suurepärastest visioonidest, ambitsioonikatest eesmärkidest ja hoolikalt läbi mõeldud tegevuskavadest pole tegelikult suurt kasu midagi, kui riigil ei ole võimalik neid ellu viia. Side keelevaldkonna rahastamise ja arengukavade vahel on aga selgelt olemas: nii eelmine kui ka praegu kehtiv arengukava on ka Haridus- ja Teadusministeeriumi keelevaldkonna eelarve planeerimise aluseks. Kuigi EKAS võeti Eesti Vabariigi valitsuses vastu küll konkreetse rahastamiskavata, on igal aastal Haridus- ja Teadusministeeriumi eelarve tegemisel arvesse võetud ka nimetatud dokumendis sisalduvaid ülesandeid. Eraldi on rahastamist leidnud ka riiklikud programmid, millest käesolevas artiklis ka veidi hiljem juttu tuleb. Uus arengukava ehk siis EKA sisaldab ka rahastamiskava aastate lõikes, mille elluviimise kogumaksumuseks 2011-2017 aasta jooksul on planeeritud üle 61 miljoni euro. Nimetatud summa ei ole loomulikult ainuke ressurss keelevaldkonna rahastamiseks. Eesti keele arengukavas ette nähtud tegevusi rahastatakse riigi ja kohalike omavalitsuste eelarve, ülikoolide ja teadusasutuste, riiklike programmide, mitmesuguste fondide ja sihtasutuste, grantide, sihtotstarbeliste eraldiste ning eri ametkondade eelarvete kaudu.

12 Tänapäevastelt strateegilistelt dokumentidelt ja eelkõige nendest lähtuvatelt tegevuskavadelt eeldatakse suhteliselt lühikese aja jooksul mõõdetavate tulemuste saavutamist, mis peaksid valdkonna või organisatsiooni viima uuele tasemele. Keele arendamise strateegilisel planeerimisel on selliste mõõdikute (indikaatorite) välja toomine raske ja üleilmastumisprotsessis võib eesti keele alal edasiminekuna defineerida pigem seniste positsioonide säilitamist näiteks inglise keele pealetungi silmas pidades. „Erinevalt paljudest teistest eluvaldkondadest ei ole keelevaldkonna arendamise põhieesmärk mitte uuele tasemele jõudmine, vaid selle tagamine, et eesti keel vastaks jätkuvalt ja edukalt nõudmistele, mida esitatakse ühiskonna ning riigi peamisele suhtlusvahendile. Keeleliste protsesside aegluse tõttu avaldub ka käesoleva arengukava vältel lahendatud ülesannete mõju paljudel juhtudel alles pärast arengukava kehtivuse lõppu. Kuna keele ning selle kasutusvaldkondade areng on pidev ning paljudest mõjuritest sõltuv, on planeerimise lähte- ja sihttaseme mõttekas fikseerimine sageli kui mitte võimatu, siis vähemalt keeruline ja äärmiselt kulukas“ (EKA: 12).

13 Et pidevalt jälgida arengukavas püstitatud ülesannete täitmist ja teostada seiret (vt Seire 2007, 2009), on keelenõukogu käivitanud ka iga 2 aasta tagant toimuvate 
Keelefoorumite sarja, kus kokku tulnud keelespetsialistide, õpetajate, poliitikute, ajakirjanike, välisekspertide ja kõigi keelehuvilistega arutatakse läbi viimase kahe aasta keelevaldkonna seisund. Et tegemist on riigi jaoks üliolulise valdkonnaga, tõestab ka fakt, et Keelefoorumitel osalevad sõnavõtuga nii Eesti Vabariigi president kui ka haridus- ja teadusminister. Nii 2007. kui ka 2009. a foorumi väliseksperdina vaagis Eesti keelevaldkonnas viimastel aastatel toimunud tegemisi Soome Kodumaiste Keelte Instituudi direktor dr Pirkko Nuolijärvi, kes võrdles Eesti ja Soome keelevaldkonna suunamist ja avaldas tunnustust süsteemse ning tulemusliku keelekeskkonna arendamise eest. Nuolijärvi tõi välja ka tegevuste olulised pidurid - keelevaldkonna liigse politiseerituse, aga ka majanduslike huvide ja keelehuvide kohatise vasturääkivuse, mis mõlemad nõuavad tähelepanu ja ei võimalda kavandatut alati kiiresti ja eesmärgipäraselt ellu viia. Paraku on mõlemad pidurid valdkonda programmeeritud: keele ühiskondlikust ja riiklikust funktsioonist lähtuvalt ei saa me keelt ja poliitikat lahus vaadata. Ka riigi ja üksikisikutest ettevõtjate majandushuvid eeldavad avatud majanduskeskkonda, tööjõu vaba liikumist, ka rahvusvahelises ruumis jms, mis väikese kasutajaskonnaga keele - nagu eesti keel - säilimisele ja arengule ei pruugi sugugi soodsalt mõjuda.

\section{Keele säilimise ja arenemise võtmevaldkonnad}

14 Keele staatuse, korpuse ja haridusega ehk siis keele planeerimise kolme põhiteemaga seonduvad eesmärgid ja tegevused on tähelepanu keskpunktis ka eesti keele strateegilisel planeerimisel. Esimene eesti keele arengukava määratles ka keele säilimise ja arenemise võtmevaldkonnad, nendeks on keelekorraldus ja keelehoole; keelekaitse; haridus ja keeleõpe; keeleuurimine; keeletehnoloogilise toe loomine (EKAS: 11). Uues, praegu kehtivas arengukavas küll taolist prioritiseerimist ei ole, kuid dokumendi visioonis sõnastatu jätkab eelnenud strateegia järjepidevust ja asetab fookusesse eesti keele toimimise vajalikul tasemel suhtlusvahendina, õpetamise, uurimise, arendamise ja kaitse: „/.../ arengukava /.../ on keelevaldkonna strateegiline alusdokument, mis koos rakendusplaani, toetavate õiguslike ja korralduslike meetmete ning rahastamisega peab aitama tagada eesti keele kui riigikeele toimimise kõikides eluvaldkondades, eesti keele õpetamise, uurimise, arendamise ja kaitse ning sellega eesti keele säilimise läbi aegade. Arengukava ellurakendamise tulemusena peab eesti keele seisund 2017. aastal olema niisugune, mis rahuldab kõiki Eesti riigi ja ühiskonna keelekasutusvajadusi, eesti keel peab olema arenguvõimeline ja tunnustatud Eesti elanike ühise suhtluskeelena.“ (EKA: 10)

Lihtsalt ära seletatuna - maailmas peaks ka tulevikus eksisteerima üks ala, üks riik, kus eesti keelt kasutatakse kõigis valdkondades kodust kõrghariduse ja teaduseni; kuigi Eesti riigi kodanikud ja elanikud oskavad ja kasutavad paljusid keeli, peaks Eestis igal pool olema võimalik eesti keeles hakkama saada.

16 Tõepoolest, keele säilimise ja arenemise jaoks on kõige tähtsam see, et teda kasutatakse. Kasutamiseks peab aga keel ise omama väljendusvahendeid kõigi eluvaldkondade jaoks kunstist ja rahvusteadustest kõrgtehnoloogia ning loodustäppisteadusteni välja; keelekeskkonna õiguslik regulatsioon peab tagama nii keele kasutamise, kaitse kui ka arengu jaoks toetavad tingimused; hariduse ja keeleõppega kindlustame keele kestmise põlvkonnast põlvkonda ja selle, et mistahes keelse kooli lõpetaja Eesti riigis on suuteline õpinguid jätkama ja/või eestikeelses keskkonnas 
töötama. Ka eesti keele staatus Euroopa Liidu ametliku keelena seab eesti keele harimisele, arendamisele ja õppimisele senisest märksa suuremad nõuded. Väga oluline on ka hoolitseda keele kui ressursi eest, sest korrastatud kirjakeelel tuginevad halduskeel, õpetuskeel, teaduskeel, avaliku teabe keel jpm, mis on ühiskonna ja riigi toimimise vältimatud eeldused.

\section{Eesti keele staatuse planeerimine}

Keele edukaks toimimiseks on vaja kindlustada ja reguleerida ka tema õigusruum. Eesti keel on Eesti riigikeel 1989. aasta keeleseaduse ja selle seaduse uute versioonide järgi. On väga tähelepanuväärne, et esimene keeleseadus võeti vastu veel enne Eesti Vabariigi taasiseseisvumist ja kandis siis nime Eesti Nõukogude Sotsialistliku Vabariigi keeleseadus, kus artiklis nr 60 seisab: „Eesti Nõukogude Sotsialistliku Vabariigi riigikeel on eesti keel. Eestimaal, eestlaste põlisel asualal on eesti keel riigi erilise tähelepanu ja kaitse all. Eesti keele seadustamisega riigikeeleks on loodud kindel alus eesti rahva ja tema kultuuri säilimiseks ja arendamiseks" (Keeleseadus 1989). 23. veebruaril 2011. aastal võttis Eesti Riigikogu vastu uuendatud keeleseaduse, mille eesmärk (nagu ka eelnenud keeleseaduse ja selle paranduste korral) on „arendada, säilitada ja kaitsta eesti keelt ning tagada eesti keele kasutamine peamise suhtluskeelena kõikides avaliku elu valdkondades“ (Keeleseadus 2011: 1.pt, \$1). Ka uus keeleseadus sätestab, et „Eesti riigikeel on eesti keel“ (Keeleseadus 2011: 2.pt, §3, lõige (1)).

Eesti keele õiguslik kaitse on jõudnud ka Eesti Vabariigi põhiseadusesse (EV Põhiseadus 2011), mille kohaselt peab riik tagama eesti rahvuse, keele ja kultuuri säilimise läbi aegade: põhiseaduse $\S 6$ sätestab, et Eesti riigikeel on eesti keel. Riigi kohustus on tagada igaühe õigus saada eestikeelset õpetust ( $\$ 37$ ); igaühe õigus eestikeelsele asjaajamisele ja suhtlemisele riigivõimuorganitega ( $(51)$; riigiasutuste ja kohalike omavalitsuste eestikeelne asjaajamine ( $(52)$.

19 Lisaks tagab põhiseadus rahvusvähemustele õiguse saada haridust emakeeles, luua kultuuri- ja haridusasutusi ning kasutada kohaliku omavalitsuse asutustes asjaajamiskeelena vähemuskeelt paikkondades, kus see vähemuskeel on enamiku elanike emakeel. Vähemusrahvuse kultuuriautonoomia seaduse kohaselt (VKAS 1993: §1) käsitatakse vähemusrahvusena Eesti kodanikke (Eesti kodanikest koosnevaid rahvusrühmi), kes elavad Eesti territooriumil.

Paraku ei saa veel väita, et eesti keele riigikeelena toimiks tõrgeteta kõigis Eesti piirkondades ja kõikides eluvaldkondades, seda nii asjaajamise ja tarbijateabe osas kui ka sellistes demokraatia toimimise seisukohalt olulistes valdkondades nagu valimisreklaami keelsus ning rahvaesindajate ja kohalike omavalitsuste valitavate tippametnike eesti keele oskus.

21 Tagamaks eesti keelele seadusalaste regulatsioonidega ette nähtud õigusi, tegeleb Eesti riik eelkõige Keeleinspektsiooni näol ka keelekaitsega. Keelekaitset on vaadeldud valdavalt järelevalve kontekstis, keskendudes ennekõike mitte-eestlaste keelekasutusele. Eesti keele säilimine ja areng sõltub aga eelkõige sellest, milline on eestlaste emakeeleoskus ning hoiak emakeele suhtes, keele maine.

22 Keelealase mainekujunduse ülesanne ongi suurendada keeleteadlikkust, kujundada keelehoiakuid ja populariseerida head keelt ühiskonnas laiemalt, et tagada keelele soodne maine kasutajate hulgas ja kõrge staatus ühiskonnas tervikuna. Hinnates eesti keele mainet kujundavaid tegureid, tuleb esile tuua rahvuslike ja konservatiivsete 
väärtuste märgatavat esiletõusu viimastel aastatel, mis toetavad positiivseid eelhoiakuid eesti keele suhtes (Seire 2009: 12). Keelest on hakatud rohkem rääkima ja kirjutama, korrektset keelekasutust väärtustama, haridus- ja teadusministri soovitusel on kõrgkoolide õppekavadesse ilmunud või ilmumas eesti keele väljendusoskust õpetavaid aineid jne. Kindlasti on eesti keelele tähelepanu pööramisele kaasa aidanud ka üle-Eestilised keelekampaaniad, näiteks eesti keele kauneima lause konkurss (eelmise haridus-ja teadusministri Tõnis Lukase algatus) või sõnaus - uute sõnade loomise võistlus, algatajaks Eesti Vabariigi president Toomas Hendrik Ilves. Sõnause võistlusele esitati üle 2000 sõnaettepaneku, eesmärgiga saada omakeelseid vasteid põhiliselt inglise keelest käibele tulnud võõrsõnadele.

Riiklikult oluline samm eesti keelega tegelemise väärtustamisel on seik, et Eesti riik annab 1989. aastast alates igal aastal välja Ferdinand Johann Wiedemanni keeleauhinda väljapaistvate teenete eest eesti keele uurimisel, korraldamisel, õpetamisel, propageerimisel või kasutamisel. Auhinna suurus on 31956 eurot (500 000 krooni), mis on Eesti majanduskeskkonda ja rahalisi võimalusi arvestades tähelepanuväärselt suur summa üksikisiku premeerimiseks.

Rahvuslikkuse tõusul on niihästi positiivseid kui ka negatiivseid kaasmõjusid. Eesti keele maine ja staatuse seisukohalt on rahvuslikkuse kasv positiivne, sest tugevdab kollektiivset identiteeti ja sellega samastumist. Et eesti keel on keskne element eestlaste identiteedis, siis tähendab see ühtlasi eesti keele suuremat väärtustamist. Samas on rahvuslikkuse tõusuga suurenenud ka tõrjuv ja sageli üsna sallimatu suhtumine Eesti venekeelsete suhtes, mis ei jäta mõju avaldamata hoiakutele eesti keele kui teise keele kasutamise suhtes.

\section{Eesti keele korpuse planeerimine}

Eesti keele arendamise strateegia üks põhieesmärke on eesti kirjakeele ja selle kasutuse hea tase. Selle saavutamiseks on oma osa keelekorraldusel, mis hõlmab üldkeele-, oskuskeele- ja nimekorralduse. Üldkeelekorraldusega tegelevad Eesti Keele Instituudi keelekorraldusosakond ja 2007. aastal Tartus tööd alustanud keelehooldekeskus. Normingute ühtsuse tagab Emakeele Seltsi keeletoimkond ja praktilisi soovitusi jagavad ka Eesti Keele Instituudi keelenõuandjad (vt Keelenõu). Keelenõu küsijate sihtrühm on olnud muutumatu läbi aegade: toimetajad, tõlkijad, riigiametnikud, ajakirjanikud, kaubandus-, toitlustus-, teenindus- ja tootmisettevõtete töötajad, kultuuriasutuste töötajad, kodanikuühenduste esindajad, õppejõud, õpetajad, õppurid, muud keelehuvilised. Pidevalt on tõusnud nende isikute arv, kes küsivad keelenõu seoses tööga riigiasutustes või Euroopa Liidu institutsioonides. Et Euroopa Liitu kuulumine on toonud eesti keelde euroterminite tulva ja spetsiifiliste vajadustega nö eurotekstid, on 2008. aastast alates Eesti Keele Instituudis tööl ka eurokeelehooldaja.

Oskuskeelekorralduse eesmärk on hea eesti oskuskeel, mis rahuldab spetsialistide vajadusi nii erialases suhtluses kui ka uurimis- või käsitlusobjekti teaduslikul tunnetamisel. Ülevaate Eesti oskussõnavara arendamise seisundist annab Eesti Terminoloogia Ühingu koostatud andmebaas ETER (ETER), mis sisaldab andmeid terminiallikate, komisjonide (kokku tegutseb Eestis 28 terminoloogiakomisjoni) ning terminoloogiaprojektide kohta valdkondade kaupa, sh terminoloogide kontaktandmeid. Saamaks oskussõnavara arendusse lisaks vajalikku rahalist ressurssi, 
käivitas Vabariigi valitsus ka riikliku programmi „Eestikeelse terminoloogia toetamine (2008-2012)".

$$
\begin{aligned}
& \text { ladus nimekorraldussüsteem, kus koostöös tegutseksid nii riikliku kui ka teadusliku } \\
& \text { nimekorraldusega tegelevad asutused. }
\end{aligned}
$$

\section{Eesti keele hariduse planeerimine}

\section{Üldharidus ja kutseharidus}

2010. aastal uuendati Eestis põhjalikult riiklik õppekava ja võeti vastu uus põhikooli- ja gümnaasiumiseadus (PGS 2010). Seadust ette valmistavates diskussioonides vaieldi palju selle üle, kas õppekavas ette nähtud emakeeletundide arv on ikka piisav, et noortest saaksid pädevad keelekasutajad. Ka 2009. aasta keelefoorumi diskussioonides kumas läbi nii õpetajate, õppejõudude kui tööandjate mure noorte kehva emakeeleoskuse pärast ja vajadus kaasata ka teiste ainete õpetajad väljendusõpetuse protsessi. Kui viimased viisteist aastat on pidevalt räägitud muukeelsete integratsioonist ja riigikeele õppest, suunatud sellele nii riigi kui ka Euroopa tähelepanu ja ressurssi, siis eesti keel emakeelena ja emakeeleõpetajate roll on pälvinud paljude meelest liiga vähe tähelepanu. Õppejõudude arvates väheneb ülikooli tulevatel gümnaasiumilõpetajatel mitte ainult keeleoskus, vaid ähmastub ka nende maailmapilt. Tööandjad kurdavad, et kõrgkoolitatud noored ei saa hakkama tööalaste kirjade veatu koostamisega; järjest enam risustab meie keelt kantseliit. Kurdetakse nii üliõpilaste emakeeleoskuse taseme kui ka puuduliku stiilitunnetuse üle. Üliõpilane ei saa näiteks sageli aru, et MSNis kasutatav eesti keel ei sobi õppejõule saadetavasse elektronkirja ja doktoritööd juhendav professor on sunnitud oma õpilase uurimust lugedes kulutama suure osa oma ajast õigekeele ja sõnastusvigade parandamisele.

Sellised hinnangud põhinevad muidugi õppejõudude subjektiivsel kogemusel, sest kirjakeeleoskuse (normeeritud kirjakeele) taseme languse kohta ei saa midagi väita, kuna pole konkreetseid võrdlusandmeid, milline on olnud tase enne ja milline see on nüüd võrreldes varasemaga. Küll aga on ette näidata üsnagi värsked andmed kõrgkoolide esmakursuslaste funktsionaalse kirjaoskuse kohta emakeeles, kus uuriti Eesti kuude avalik-õiguslikku ülikooli pääsenuid (Ehala, Kerge, Lepajõe, Sõrmus 2010). Uuringu järgi on ligi $20 \%$ esimese aasta üliõpilastest sisuliselt puuduliku emakeeleoskusega. Ja tegemist on kindlasti noorte eliidiga, sest ülikoolidesse asub õppima siiski akadeemiliselt võimekam osa keskhariduse omandanutest. Kuid ka sellel kontingendil on muret tekitavalt kehvad näitajad emakeeles, mis võib lõppkokkuvõttes tugevasti pärssida selliste üliõpilaste akadeemilist edukust ülikoolis.

Alus elujõulisele eesti keelele pannakse muidugi kodus ja koolis. Kõrgkool saab seda elujõudu omakorda juurde anda ja peabki seda tegema, säilitades ja arendades ka kõrghariduses ja teaduses eesti keelt. Kui noor spetsialist ei saa hakkama keeleliselt ja stiililt korrektse ametikirja koostamisega ning üliõpilane saadab professorile e-kirja, kus ta kõnetab teda kui eakaaslasest tuttavat, on noore inimese emakeeleoskuse ja erinevate keelestiilide valdamisega midagi olulist lahti. Gümnaasiumi vajaka jäämisi emakeeleõpetuses on kõrgkoolid sunnitud korvama sellega, et õppekavas nähakse ette kohustusliku või valikainena eesti kirjakeele, suulise ja / või kirjaliku väljendusoskuse, erialakeele jms ained. Näiteks Tartu Ülikoolis on selline kohustuslik aine ülikooli nõukogu otsusega kõigi erialade üliõpilaste õppekavas. 
31 Viimaste aastate üks olulisemaid muutusi Eesti hariduse korralduses oli kindlasti 2007/2008. õa-l alanud üleminek osalisele eestikeelsele õppele muukeelses üldhariduskoolis, mille kohaselt peaks 2013. aastaks kõigis mitte-eestikeelsetes gümnaasiumides toimuma õpe $60 \%$ ulatuses eesti keeles.

32 Mahukatel uuringutel põhinevate järelduste kohaselt on kasvanud nii muukeelsete noorte huvi eesti keele vastu kui ka tööturule sisenevate noorte mitte-eestlaste eesti keele oskus. Nii toob ka Eesti Lõimumiskava 2008 - 2013 (LK 2008) ja selle 2010. aastal toimunud monitooring (LK monitooring 2010) välja, et praeguste noorte ja keskealiste Eesti elanike seas on ühiseks suhtluskeeleks kujunenud eesti keel, venekeelse elanikkonna seas on paranenud ka enesehinnang oma eesti keele oskusele, eestlased ja venelased tunnustavad ja usaldavad üksteist varasemaga võrreldes rohkem, mõlemalt poolt tajutakse vajadust panustada integratsiooniprotsessidesse, sealjuures ei kardeta kaotada oma rahvuslikku eripära. Monitooring toob välja ka selle, et Eestit tabanud majanduskriisis oli venekeelne elanikkond suuremaks kannatajaks ja ka selle, et venekeelsete arvates, on eestlastel paremad võimalused materiaalseks heaoluks, poliitiliseks tegevuseks ja ka haridusvõimalusteks lastele.

Eraldi peab välja tooma venekeelsete kutsekoolide lõpetajate probleemid, mis nõuavad lähiaastatel lahendamist, vt Vajadusuuring 2009. Eesmärk, et ka muukeelse kutsekooli lõpetaja saaks edukalt hakkama eestikeelses töökeskkonnas või eestikeelses jätkuõppes, ei ole praeguseks täitunud. Üheks ja väga oluliseks põhjuseks on kindlasti asjaolu, et kutsekoolidele ei kohaldata $\mathrm{ka}$ muukeelses gümnaasiumis eestikeelse õppe kohustuslikkust $60 \%$ ulatuses. Tõsi, ka siin on muutusi märgata. Aasta aastalt väheneb ainult vene keeles õpet pakkuvate koolide arv, piirdudes hetkel vaid nelja erakooli ja ühe riigi kutseõppeasutusega. Pidevalt on suurenenud koolide arv, mis pakuvad õpet mõlemas keeles või ainult eesti keeles. Kui 2005/06. õppeaastal õppis vene õppekeelega rühmades $32 \%$ õpilastest, siis 2009/10. õppeaastaks on vene keeles õppijate arv kahanenud 25\%-ni õppurite koguarvust, vt EHIS.

\section{Kõrgharidus ja teadus}

Keele kasutusaladest on üks võtmevaldkondi kindlasti kõrgharidus ja teadus. Isegi sellised keeled, mida kõnelevad emakeelena kümned miljonid inimesed, ei pruugi end oma tuleviku suhtes pikas perspektiivis sugugi turvaliselt tunda, kui selles keeles puudub kõrgharidus (vt ka Crystal 2000: 13).

2003. aasta sügisel tähistas Tartu Ülikool 200 aasta möödumist eesti keele ülikooliõppe algusest, kui Tartu Ülikoolis avati eesti ja soome keele lektoraat, mis esmakordselt maailmas arvas eesti keele ja soome keele ülikoolis õpetatavate ainete hulka. Eestikeelsest kõrgharidusest võime rääkida alates 1919. aastast, kui iseseisvunud Eesti Vabariigis taasalustas tööd Tartu Ülikool. Kuigi paljud tolleaegsed professorid olid välismaalased, hakkas ülikool suhteliselt kiiresti kasutama eesti keelt õppekeelena.

Eesti keel kõrghariduse ja teaduse keelena on Euroopa mastaapides muidugi nooruke ja samas ka unikaalne: vaevalt võiks peale islandi keele nimetada eesti keele kõrvale veel mõnda nii väikese kõnelejaskonnaga keelt Euroopas, mis on suutnud välja arendada emakeelse kõrghariduse ja teaduse. Eesti keele hoidmine ja arendamine kõrghariduses ja teaduses on kindlasti olulisimaid indikaatoreid elujõulise keele säilimises, kuna loob eeldused kultuuri kestmiseks ja edendamiseks, rääkimata panusest Euroopa ja maailma kultuurilise ja keelelise mitmekesisuse säilimisse. Miljonilise emakeelse 
kõnelejaskonnaga keel kõrghariduse ja teaduskeelena on kahtlemata eestlaste suurimaid saavutusi.

Eesti keele kui kõrghariduskeele sälimise ja arengu suurimaks ohustajaks on tänapäeva maailmas toimuv inglise keele pealetung kõigis eluvaldkondades. Erandiks pole ka kõrgharidus. Ka eesti keelest kümneid kordi suurema kasutajaskonnaga keelte puhul räägitakse vajadusest luua meetmed emakeelse kõrghariduse ja teaduse arendamiseks. Teisalt on aga Euroopa kõrgharidusruum ideaalis avatud ja rahvusvaheline, mis eeldab ka mitmekeelset ülikooli. Kindlasti peame arvestama asjaoluga, et inglise keele prestiiž tõuseb jätkuvalt. Ka Eestis on eriti suuremates linnades võimalik hakkama saada ainult inglise keeles. Tartus õppivad välisüliõpilased kurdavad, et ei saa piisavalt eesti keelt praktiseerida, kuna eestlased lähevad pigem inglise keelele üle, kui ootavad kannatlikult, millal välismaalane oma konarlikus eesti keeles lause lõpetab. Rahvusvaheliste ettevõtete töökeel Eestis on tavaliselt inglise keel. Väga hea inglise keele oskus on muutunud vältimatuks karjääri tegemise eelduseks nii kodus kui ka välismaal.

Kui võrrelda mõlemas arengukavas püstitatud eesmärke kõrghariduse (ja sellega seotult ka teaduse) valdkonnas, siis endiselt on oluline tagada eestikeelse kõrghariduse jätkumine ja vältida mis tahes teadusala täielikku võõrkeelestumist. Selleks nähakse ette, et kõigil õppeastmetel ja kõigis õppekavarühmades oleks võimalus eestikeelseks õppeks ning tähtsamad teadustulemused leiaksid avaldamist ka eesti keeles (EKAS: 29, EKA: 47-50).

2011. aastal õpib Eestis ülikoolides ja rakenduskõrgkoolides ligi 68000 üliõpilast, kes siis õpivad kas eesti, vene või inglise keeles. Ülikooliseaduse (ÜS 2010: § $22 \lg 8$ ) ja rakenduskõrgkooli seaduse (RS 2010: §17) järgi on kõrghariduse tasemel õppekeeleks eesti keel, muude keelte kasutamise otsustab haridusasutuse nõukogu või haridus- ja teadusminister. Kõrgkoolid on seega üsna vabad ise oma õppekavade keelsust määrama. Kõrgkoolides toimub 2010/2011 89\% õppest eesti keeles, 2\% inglise keeles ja $9 \%$ vene keeles. On tähelepanuväärne, et eestikeelse ja mitte-eestikeelse õppe suhtarvud on viimase viie aasta jooksul jäänud samaks: ka 2005/2006. õa õppis $89 \%$ üliõpilastest eestikeelsetel õppekavadel, veidi rohkem oli kokkuvõttes venekeelset õpet - $10 \%$ ja veidi vähem ingliskeelset - $1 \%$. Vene õppekeelega üliõpilaste osakaalud on oluliselt suuremad erarakenduskõrgkoolides ja eraülikoolides (2009/10 õa vastavalt $45 \%$ ja 17\%), kuid selliste koolide üliõpilaste protsent Eesti üliõpilaste hulgas on suhteliselt väike. Eestikeelse õppe osakaal kasvab magistri- ja doktoriõppes ning vene õppekeele osakaal on kummalgi juhul alla 1\%. Kõrgkoolide statistilised andmed pärinevat Haridus- Teadusministeeriumist, vt Kõrghariduse statistika.

Eesti seadused võimaldavad üliõpilastel, kelle eesti keele oskus ei ole piisav, õppida lisaks eesti keelt süvendatult. Eesti keele kursused võivad eelneda korralisele õppetööle, kuid sagedasem on praktika, kus muukeelsetele üliópilastele pakutakse erialaõpingutega paralleelselt ka keeleõpet kas eraldi kursuste vormis või siis lõimitud aine- ja keeleõppe moel. Kõrgkooli astuvate muukeelsete noorte eesti keele oskuse tase on ka viimastel aastatel tõusnud ja tõenäoliselt tõuseb veelgi. Seda toetab nii kakskeelne õpe gümnaasiumis kui ka asjaolu, et umbes $25 \%$ muukeelsetest lastest on asunud õppima eestikeelsesse kooli või keelekümblusklassi, vt ka Klaas 2011.

41 Ülikoolid on viimastel aastatel loonud juurde märkimisväärsel hulgal osaliselt või täielikult võõrkeelseid õppekavu nii humanitaarteadustes ja kunstis, sotsiaalteadustes, loodus-, tehnika- ja täppisteadustes. Eesti riik ergutab siin ka ülikoolide vahelist 
koostööd, eraldades märkimisväärseid rahalisi ressursse just ühisõppekavade avamiseks. Ingliskeelse õppe osakaalu tõus, eriti magistriõppes, rääkimata doktoriõppest, on ka teistes Euroopa riikides täheldatav suundumus. Eesti kõrgkoolid kui osa Euroopa kõrgharidusruumist seavad endale eesmärgiks avatud ja kvaliteetse õpikeskkonna, mille realiseerimist nähaksegi paljuski just ingliskeelses õppes. Samal ajal ennustab Eestis saabumas demograafiline kriis aga potentsiaalsete üliõpilaste (st gümnaasiumide lõpetajate) arvu langust lähema 5 aasta jooksul koguni $40 \%$. Demograafilist auku loodavad kõrgkoolid täita just välisüliõpilaste abiga, kes eeldatavasti tuleksid õppima just ingliskeelsetele kavadele.

Eesti riik on valinud välja ka mõned rahvusvaheliselt atraktiivse potentsiaaliga óppekavad, mida on ka rahaliselt olulisel määral toetatud (näiteks semiootika Tartu ülikoolis) ja mis lubab pakkuda välisüliõpilastele tasuta õppimisvõimalust ja stipendiume. Suurem osa ingliskeelsetest õppekavadest on aga tasulised, st üliõpilased peavad tasuma õppemaksu. Kuna näiteks Skandinaavia riikides on kõrgharidus tasuta ja ka välisüliõpilased ei pea õppemaksu maksma, on Eestil oma valdavalt tasuliste ingliskeelsete programmidega raske püsida siin konkurentsis. See on ka üks põhjustest, miks välisüliõpilaste osakaal pole Eestis veel olulist kasvumärki näidanud.

Väga rõõmustav on fakt, et rahvusvahelist õpet toetavate tegevuste kõrval rõhutab Eesti riik eestikeelse kõrghariduse jätkumise vajadust ja erilist toetust eestikeelsele õppele ka 2011. aastal uue valitsuse koalitsioonileppes (Valitsusprogramm 2011). Ka Eesti keele arengukava näeb eestikeelse õppe säilimise kõikidel erialadel ühena oma peamistest eesmärkidest.

On asjakohane ja ajast sõltuv, et kõrghariduse arengutes otsitakse tasakaalu rahvusliku ja rahvusvahelise vahel ja kõrgkoolide juhtkonnad püüavad langetada otsuseid, mis tagaksid koolile ühelt poolt rahvusvahelise avatuse ja nähtavuse, teisalt säilitaksid ja arendaksid eestikeelset õpet kõigil erialadel. Eesti kõrghariduse rahvusvahelistumise strateegia näitab küll suunda doktoriõppe muutumisele ingliskeelseks, ka magistriõppes püüab riiklik kõrghariduse rahvusvahelistumise poliitika ergutada ingliskeelse õppe kasvu, kuid mõistlik tasakaal rahvusvahelise ja eestikeelse õppe vahel on vähemalt seni säilinud.

Eesti keele positsioon kõrghariduse keelena on tihedalt seotud eesti keelega teaduses. Teaduse lingua francaks on viimase 50 aasta jooksul kogu maailmas muutunud inglise keel ja Eestis tehtav teadus pole siin erandiks. Eestikeelsete teadusartiklite ja kraaditööde arv väheneb aasta-aastalt. Kui nõukogude ajal toimus väitekirjade kirjutamine ja kaitsmine vene keeles sunniviisiliselt, siis praegu eelistab enamik teadlasi publitseerida võõrkeeles samuti keskkonna surve tõttu. Ja nendeks survestajateks on akadeemilise maailma reeglid, mis väärtustavad enam ingliskeelseid artikleid ja publitseerimist välismaal. Missiooniteadlike teadlaste eestikeelne toodang on paljuski nende nö eralóbu, mis akadeemilise tegevuse hindamisel arvesse ei lähe. Ja survestajaks on ka lihtsalt väikekeelte jaoks karm reaalsus: et toodang teadusmaailmas leviks, peab see olema ingliskeelne.

Väidete kinnituseks mõned andmed Tartu ülikoolis viimastel aastatel kaitstud doktoritööde ja teaduspublikatsioonide keele kohta. Tartu ülikoolis aastatel 2000-2010 kaitstud doktoritöödest on 16,3\% kirjutatud eesti keeles, 78,6\% inglise keeles, 3,7\% vene keeles, $1,4 \%$ saksa keeles ja $0,1 \%$ prantsuse keeles. Viimased 3 aastat on toonud kaasa eestikeelsete doktoritööde hulga märkimisväärse vähenemise: näiteks 2010. aastal kaitstud töödest on alla $10 \%$ eestikeelsed. Loodusteaduste, täppisteaduste ja meditsiini 
valdkondades kirjutatakse doktoritöid ainult inglise keeles. Ka sotsiaalteaduste puhul võime rääkida peaaegu $100 \%$-liselt ingliskeelsetest doktoritöödest, erandiks on õigusteadus ja haridusteadus, kus küllaltki palju kaitstakse ka eesti keeles. Humanitaarteaduste vallas on doktoritöödest 2000-2010 olnud küll 56,4\% eestikeelsed. Kuid ka selles valdkonnas on just viimastel aastatel märgata eestikeelsete doktoritööde arvu vähenemist ja ingliskeelsete arvu suurenemist. Nii oli 2010. a Tartu Ülikoolis kaitstud humanitaarteaduste valdkonda kuuluvatest väitekirjadest juba ainult $38 \%$ eestikeelsed.

Eesti teaduse infosüsteemi põhjal (ETIS) on ajavahemikus 2000-2007 ilmunud TÜ teaduspublikatsioonidest umbes $65 \%$ kirjutatud inglise keeles ja $25 \%$ eesti keeles. Vene keel on publikatsiooni keeleks märgitud $4,5 \%$ ja saksa keeles ca $3 \%$ publikatsioonide juures. Ülejäänud keelte osakaal jääb alla $1 \%$, seejuures on soome, prantsuse, itaalia ja hispaania keele osa üle $0,1 \%$. Ka viimased aastad on tendents sama. Aastatel 2000-2007 on teadustulemuste publitseerimisel kasutatud ligi 40 erinevat keelt. TÜ teadlaste publitseeritud teadusartiklid, mida indekseerib ISI Web of Science andmebaas, on valdavas enamuses (98-99\%) kirjutatud inglise keeles. Põhjuseks on muidugi ka asjaolu, et nimetatud andmebaas sisaldabki enamjaolt ingliskeelseid väljaandeid. Eestikeelsete artiklite osakaal on viimase 7 aasta jooksul jäänud alla $0,5 \%$. Teiste keelte osakaal on samuti väike, varieerudes aastati $0,2-1,2 \%$ vahel

Ka eesti keele alane uurimistöö on peamiselt artiklipõhine ja paljuski ingliskeelne. Puudust tuntakse just mahukatest tervikkäsitlustest. Viimaste aastate tähelepanuväärseima väljaandena tuleb kindlasti nimetada ligi 150000 märksõnaga „Eesti kirjakeele seletussõnaraamatu” (EKS) valmimist 2009. aastal. Eestikeelsete tervikkäsitluste puudumine on peaasjalikult tingitud teadlaste vähesest motiveeritusest nende kirjutamiseks ja koostamiseks. Kuna teadusrahastamise, aga ka akadeemilistele kohtadele valimise ja tagasivalimise jaoks annavad hindamisel oluliselt suurema väärtuse monograafiate asemel rahvusvahelistes teadusajakirjades publitseeritud artiklid, on humanitaarteadlased investeerinud oma aega pigem näiteks kolme 10-leheküljelisse artiklisse kui 300-leheküljelisse tervikkäsitlusse. Loetelus esimene annab teadusteema (ja seega ka raha) taotlemiseks vajaliku hulga publikatsioone, teine aga mitte, samas on artiklite kirjutamine kordades vähem ajamahukam monograafiaga võrreldes.

Üks oluline tahk eesti keelel kõrghariduses on ka eesti keele akadeemilisel välisõppel. Seda, et viimastel aastatel väärtustatakse üha enam eesti keele õppimist ja õpetamist välismaa ülikoolides, tuleb pidada kindlasti eesti keele positsioonide kindlustamisel väga tähtsaks. Eesti riigi huvides on kahtlemata Eesti-sõbralike inimeste rohkus väljaspool Eestit. Nutikad riigid on juba ammu aru saanud sellise pehme välispoliitika kasuteguritest ja toetavad oma maa, keele ja kultuuri õpetamist ja tutvustamist välismaal. Näiteks Soome riik toetab soome keele õpetamist pea 90 välisülikoolis. Eesti keelt oli 2010. aastal võimalik õppida 34s välismaa ülikoolis Euroopas, Ameerikas ja Aasias. Eesti keele ja kultuuri akadeemilise välisõppe programm (EKKAV) näeb ette ópetuskeskuste asutamise välisülikoolidesse koos õpetajate ettevalmistuse ja täienduskoolitusega, stipendiumitega uurimis- ja õppetööks Eestis, samuti õppevara arendamisega seonduvad tegevused ja palju muud olulist. Praeguseks töötavad Eesti riigi toel lektorid 10 ülikoolis: Leedus Vilniuse Ülikoolis ja Venemaal Peterburi Riiklikus Ülikoolis 2002. aastast; Prantsusmaal Pariisi Ida Keelte ja Kultuuride Instituudis (INALCO) 2003. aastast; Saksamaal Göttingeni Georg Augusti Ülikoolis 2005. aastast; 
Suurbritannias Glasgow’ Ülikoolis 2006. aastast; Poolas Varssavi Ülikoolis 2007. aastast; Venemaal Moskva Riiklikus Ülikoolis 2008. aastast; Ukrainas Lvivi Ivan Franko nimelises Rahvusülikoolis ja Tšehhis Brno Masaryki Ülikoolis 2009. aastast; Hiinas Pekingi Välisõpingute Ülikoolis (Beijing Foreign Studies University) alates 2010. Järjekorras ootab mitu mainekat Euroopa ülikooli. Järgmiseks õpetuskohaks on 2011. aasta sügisest Läti Ülikool Riias.

\section{Keelevaldkonna arengut toetavad riiklikud programmid}

Juba kümmekond aastat on Eestis toetatud riiklikult olulisi tegevusi, sh ka teadus- ja arendustegevust muuhulgas ka riiklike programmide abil. Riiklikud programmid töötavad erinevate ministeeriumide juhtimisel ja on loodud konkreetsete ülesannete lahendamiseks, kandes endas projektipõhisuse ideoloogiat. Kiire majanduskasvu aastad lubasid käivitada ja rahastada mitmeid riiklikke programme, eraldada raha uurimis- ja arendustegevuseks. Sellest hoolimata, et aastatel 2009 ja 2010 vaevles Eesti nagu ka muu Euroopa raskes majanduskriisis, jätkus siiski ka nendel aastatel programmide rahastamine. Keelevaldkonna riiklikud programmid (ka lõppenud), millele alljärgnevalt viidatakse, koos rahastatud projektidega võib leida Haridus- ja Teadusministeeriumi koduleheküljelt, vt HTM Riiklikud Programmid.

Riiklikud programmid on oluliselt aidanud kaasa ka keelevaldkonna arendamisse. Kuna eesti keele keeletehnoloogilise toe loomine on olnud üks keelevaldkonna olulisemaid ülesandeid, siis tõstaksin riiklike programmide seast esile just 2006. a käivitunud programmi „Eesti keele keeletehnoloogiline tugi (2006-2010)”, kus kavandatud tegevused on ka kõik ette nähtud ulatuses täidetud: näiteks eesti keele koondkorpuse maht on nüüdseks umbes 180 miljonit sõna; eesti kõnekeele (suulise keele) korpuse maht on umbes 365 tundi kõnet; loodud on erikorpused, mis on vajalikud kitsamalt piiritletud ülesannete täitmiseks: näiteks inglise-eesti euroseadustekstide paralleelkorpus sisaldab nüüdseks 12 miljonit sõna.

2011. aastast on käivitatud ka uus riiklik programm „Eesti keeletehnoloogia 2011-2017", mis jätkab varasema keeltehnoloogia programmi tegevusi. Jätkuprogramm eristub eelnevast programmist selle poolest, et lisaks tarkvaraprototüüpide ja keeleressursside arendamisele pööratakse suurt tähelepanu keeletehnoloogia rakenduste loomisele ja olemasolevate ning loodavate ressursside ning tarkvara kättesaadavaks tegemisele.

Oluline on see, et ka teiste riiklike programmide (nt „Eesti keel ja rahvuslik mälu (20042008)”, „Rahvuskaaslaste programm” (2004-2008), „Eesti keele ja kultuuri akadeemilise välisõppe programm (2005 -2010)”, „Hõimurahvaste programm” (2005-2009)) rahastamine on olnud järjepidev ning projektidele eraldatavad summad on kasvanud.

2008. aastal käivitusid programmid „Eestikeelse terminoloogia toetamine (2008-2012)”, „Eestikeelsete kõrgkooliõpikute koostamine ja väljaandmine” (2008-2012) ning „Keeleõppe arendamine 2007-2010”. Kui kõik läheb kavandatult, on meil igal aastal ilmumas kümmekond erinevate erialade üliõpilastele mõeldud eestikeelset õpikut käsiraamatut, kus on läbi töötatud oskussõnavara mäendusest, geneetikast, patoloogiast tähendusõpetuse ja logopeediani välja. Selleks on kavandatud riiklikest vahenditest kavandatud 1, 25 miljonit eurot. 

2008. aastal lõppenud analoogilisi eesmärke täitnud programmi „Eesti keel ja rahvuslik mälu (2004 - 2008)“. Programmi põhieesmärk on olla eesti keele alase teadustöö rahaline toetusinstrument, näiteks krestomaatiliste suurteoste väljaandmisel. Sel moel püütakse katta ka tarvet eesti keele alaste tervikkäsitluste koostamise vallas. Samuti toetatakse keeleteaduslike andmebaaside korrastamist, digitaliseerimist ja publitseerimist, eesti keele populariseerimist, humanitaarteaduslike väljaannete taseme tõstmist ja neile rahvusvahelise tunnustuse saavutamist jm olulisi tegevusi.

Kultuuriministeeriumi eelarvest on rahastatud programmi „Lõunaeesti keel ja kultuur“ (2000-2004; 2005-2009) ning „Setomaa riiklik kultuuriprogramm 2006-2009”, lisaks on Kultuuriministeerium algatanud programmid „Kihnu kultuuriruum 2008-2010” ja „Saarte pärimuslik kultuurikeskkond 2008-2010”, vt KM Riiklikud Programmid.

\section{Kokkuvõte}

Kokkuvõtvalt võib tõdeda, eesti keele käekäik 21. Sajandi alguses annab tunnistust, et tegemist on elujõulise ja arenemisvõimelise keelega, mille staatuse, korpuse ja hariduse planeerimisega tegeldakse riiklikul tasandil. Miljon emakeelset kõnelejat ja lisaks veel paarsada tuhat neid, kes kasutavad sageli eesti keelt kas teise keelena või võõrkeelena on igati arvestatava suurusega kasutajaskond. Seni püsib eesti keel ka kõigis võimalikes kasutusvaldkondades, teenides inimesi, riiki ja ühiskonda nii instrumendina, ühiskonna sidustajana kui ka kuluturimälu kandjana. Teatud ohu märgid ilmnevad siiski eesti keele järjest väiksemas kasutuses teaduse keelena. Kui kõrghariduses aga jätkub endiselt eestikeelse õppe valdav domineerimine ja eestikeelsete õppekavade pakkumine kõigil erialadel, on sel moel võimalik tasakaalustada rahvusvahelisele auditooriumile suunatud teadustulemuste publitseerimise paratamatut ingliskeelsust ja vältida mõne eriala täielikku kadumist eestikeelsest kultuuriruumist.

\section{BIBLIOGRAPHIE}

\section{Viidatud kirjandus ja elektroonilised allikad}

Crystal $2000=$ David Crystal, Language death, Cambridge University Press, 2000.

Eesti 2011 = Eesti. Arve ja fakte 2011, Tallinn, Eesti Statistikaamet.

Eesti inimarengu aruanne 2007 = Eesti Koostöö Kogu (2008). Eesti inimarengu aruanne 2007. Eesti Ekspressi Kirjastuse AS, Tallinn.

Eesti Statistikaamet $=$ Eesti statistikaameti kodulehekülg .

Eesti Statistikaamet $2001=2000$. aasta rahvaloenduse tulemused, II kogumik - Kodakondsus, rahvus, emakeel ja võõrkeelte oskus, Tallinn.

Ehala, Kerge, Lepajõe, Sõrmus 2010 = Martin Ehala, Krista Kerge, Kersti Lepajõe, Kadri 
Sõrmus, Kõrgkoolide üliõpilaste eesti keele oskuse tase. Uuringukokkuvõte. Tartu: Tartu Ülikool 2010.

EHIS = Eesti Hariduse Infosüsteem.

EKA = Eesti keele arengukava 2011-2017, Eesti Keele Sihtasutus, Tallinn, 2011

EKAS $=$ Eesti keele arendamise strateegia 2004-2010, Tartu, 2004

EKKAV = Eesti keele ja kultuuri akadeemilise välisõppe programm 2011-2017.

EKS = Eesti Kirjakeele Seletav Sõnaraamat, toimetanud Margit Langemets, Mai Tiits, Tiia Valdre, Leidi Veskis, Ülle Viks, Piret Volli, Eesti Keele Sihtasutus, Tallinn, 2009.

ETER = Eesti Terminoloogia Ühingu andmebaas.

ETIS $=$ Eesti teaduse Infosüsteem.

EV Põhiseadus 2011 = Eesti Vabariigi Põhiseadus, Riigi Teataja I, 27.04.2011, 2

Ferguson 2006 = Ferguson, Gibson. Language Planning and Education. Edinburgh University Press. Hornberger, Nancy H. 2006.

HTM Riiklikud Programmid = Haridus- ja Teadusministeeriumi riiklikud programmid, Keeleseadus 1989 = ENSV keeleseadus, ENSV ÜN ja Valitsuse Teataja 1989, Nr. 4: 81-86, Tallinn Keeleseadus 2011 = Eesti Vabariigi keeleseadus, Riigi Teataja I, 18.03.2011, 1.

Keelenõu = Eesti Keele Instituudi keelenõuanne.

KM Riiklikud Programmid = Kultuuriministeeriumi Riiklikud programmid, lingid aadressil http://www.kul.ee/index.php?path=407 ja http://www.kul.ee/index.php? path=0x7x1554\#kultuuriruumid

Klaas 2011 = Vene kool vajab järjepidevust, Eesti Päevaleht, 26.01.2011

Kõrghariduse statistika = Kõrgkoolide statistilised andmed.

LK 2008 = Eesti Lõimumiskava 2008 - 2013.

LK monitooring 2010 = Eesti lõimumiskava eesmärkide saavutamise monitooring 2010

Mansoor, Sabiha 2005 = Language Planning in Higher Education. New York: Oxford University Press, 2005

PGS 2010 = Põhikooli- ja Gümnaasiumiseadus, Riigi Teataja 2010, 41, 240.

RS $2010=$ Rakenduskõrgkooli seadus.

Seire 2007 = Eesti keele arendamise strateegia (2004-2010) elluviimine 2004-2006, Tartu, 2007

Seire 2009 = Eesti keele arendamise strateegia (2004-2010) elluviimine 2007-2008, Tartu, 2009

Stewart 1968 = Stewrt, William A., Sociolinguistic Typology of Multilingualism. - Readings in the Sociology of Language. Ed. Joshua Fishman. The Hague: Mouton Publishers, 1968.

Vajadusuuring 2009 = Eestikeelse õppe laiendamine vene õppekeelega õpperühmadega kutseõppeasutustes.

Valitsusprogramm 2011 = Erakonna Isamaa ja Res Publica Liit ning Eesti Reformierakonna valitsusliidu programm.

VKAS 1993 = Vähemusrahvuse kultuuriautonoomia seadus, Riigi Teataja I, 26.10.1993, 71, 1001 
Wiley, Terrence G. 2003 = Frameworks and Models in Language Policy and Planning, - Thomas Ricento, An Introduction to Language Policy, Wiley-Blackwell, pp 24-41.

ÜS $2010=$ Ülikooliseadus.

INDEX

Index chronologique : XXIe siècle (début), XXIe siècle 